\title{
ISLANDSK KRONIK 1994-1999
}

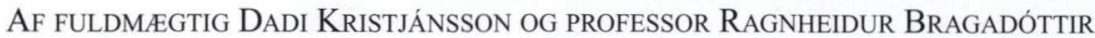

\section{Indledning}

For seks år siden blev der sidst trykt en islandsk kronik i NTfK, hvori der bl.a. blev gjort rede for ændringer i straffeloven i perioden 1984-1993, samt andre nye og ændrede love inden for strafferet og retspleje i perioden 1988-1993. I denne kronik er det hensigten at give en oversigt over ændringer i straffeloven og retsplejeloven i perioden 1994-1999. Der vil endvidere blive gjort rede for ændringer i politiet, og i fængselslovgivningen. Til slut omtales andre nye love og lovændringer, der har betydning på det kriminalretlige område.

\section{Andringer i straffeloven 19/1940 i perioden 1994 til 1999}

\section{Foranstaltninger til hindring af skattesvig}

Med lov nr. 39/1995 blev der indført en bestemmelse i straffelovens $§ 262$ om grove krænkelser af bestemte skattelove og bogføringslove, derunder overtrædelser, som er begået i det øjemed at skjule egen eller andres berigelsesforbrydelse. I bestemmelsen gøres der rede for, hvilke skattesvigs- og bogføringslovovertrædelser, som defineres som grove. Det er de tilfælde, hvor det drejer sig om store pengebeløb, forbrydelser begået under anvendelse af en særlig forkastelig metode eller under omstændigheder, der i høj grad forøger forbrydelsens grovhed, samt gentagelsestilfælde. Subjektivt kræves der forsæt eller grov uagtsomhed. Bestemmelsens strafferamme er op til seks års fængsel, og det er endvidere tilladt at idømme bøde for forbrydelser mod de af skattelovens bestemmelser, der nævnes i $§ 262$.

\section{Afskaffelse af straffelovens $\S 108$ om arekrankelser mod offentligt ansatte}

Med lov nr. 71/1995 blev en særlig bestemmelse om ærekrænkelser mod offentligt ansatte, straffelovens $\S 108$, ophævet. Ændringen har rod $\mathrm{i}$ en betænkning fra et udvalg, som Justitsministeren nedsatte i kølvandet af Den europæiske Menneskerettighedsdomstols dom af 25. juni 1992 i en sag mod den islandske stat. Domstolen fandt, at den islandske stat havde overtrådt menneskerettighedskonventionens $\S 10$ ved at straffe en person i Islands Højesteret for ærekrænkelser mod politiet og enkelte politifolk i Reykjavík i medfør af straffelovens $\S 108$. Udvalget mente i lyset af menneskerettighedsdomstolens dom, at bestemmelsen kunne hindre befolkningen $\mathrm{i}$ at nyde den vigtige rettighed, som består i at kunne kritisere anliggender af muligt stor offentlig betydning. Endvidere mente udvalget, at bestemmelsen ikke var i overensstemmelse med det grundlæggende princip om borgernes ligestilling. Udvalget foreslog derfor bestemmelsen afskaffet, da offentligt ansatte, ligesom andre borgere, er beskyttet af de almindelige bestemmelser om ærekrænkelser i straffelovens $\S \S$ 234-241. En særlig tiltalebestemmelse blev endvidere foreslået indsat i straffelovens $\S 242$, nr. 2 b, hvorefter en ærekrænkende fornærmelse, som rettes mod en person i dennes egenskab af offentligt ansat, undergives betinget offentlig påtale.

\section{De forenede Nationers konvention om beskyttelse mod tortur}

I 1995 ratificerede Island De forenede Nationers konvention om beskyttelse mod tortur og anden brutal og umenneskelig eller nedværdigende behandling eller straf af 10. december 1984. Med henblik på at opfylde konventionens bestemmelser blev der ved lov nr.142/1995 føjet et nyt nr. 9 til straffelovens $\S 6$, således at det nu er muligt at straffe personer for handlinger, som omfattes af konventionen uden hensyn til statsborgerskab, bopæl eller gerningssted. Sagsanlæg kræver dog Justitsministerens godkendelse. 


\section{Bornepornografi}

Med lov nr. 126/1996 blev der føjet et nyt stykke 4 til straffelovens $\S 210$ om pornografi. Ifølge den ny bestemmelse er det strafbart at besidde fotografier, film eller lignende, der afbilder børn på en kønslig eller utugtig måde eller viser børn, der har kønslig omgang med dyr eller anvender genstande på en utugtig måde. Overtrædelse af bestemmelsen straffes med bøde. Ved lovforberedelsen toges hensyn til § 235 i den danske og $\S 211$ i den norske straffelov.

Det er ingen betingelse for strafbarheden, at der er blevet begået en seksualforbrydelse mod barnet ved optagelse af billedstoffet, eller at den, som besidder materialet, har i sinde at distribuere børnepornografi. Besiddelse af materialet er tilstrækkeligt til at pådrage strafansvar. Med besiddelse menes ud over at eje materialet bl.a. at materialet haves til låns, leje eller opbevaring. Ved mekanisk distribution $\mathrm{fx}$ af fjernsynsudsendelser eller billeder, der hentes i databanker til beskuelse på egen computerskærm, anses billederne ikke for at være i beskuerens besiddelse. Hvis billederne derimod er optaget på videobånd, overflyttet til en computers harddisk, diskette eller cd, således at vedkommende selv kan hente billederne, anses han for at besidde materialet. Barnets alder nævnes ikke i bestemmelsen, men den opfattes som gældende for børn under 18 år. Hvis forsæt til at distribution af materialet kan bevises, falder handlingen under straffelovens $\S 210$, stk. 2, som straffes med bøde eller fængsel i op til 6 måneder.

\section{Beskyttelse mod diskrimination}

På grund af Islands internationale forpligtelser om afskaffelse af racisme blev der foretaget ændringer i straffeloven ved lov nr. 135/1996. På den ene side blev der indsat bestemmelser i straffelovens $\S 180$ om diskrimination. Dér står, at i offentlige arbejds- eller servicevirksomheder er det strafbart at nægte en person handel eller service på grund af dennes nationalitet, farve, race, religion eller seksualitet. Det er endvidere af samme grund strafbart at formene folk adgang til offentlige steder på lige fod med andre. På den anden side blev der foretaget to ændringer i straffelovens $\S 233 \mathrm{a}$. For det første blev bestemmelsen ændret, således at bestemmelsen i stedet for kun at fremhæve en gruppe personer, der nyder beskyttelse mod at blive overfaldet offentligt med hån, bagvaskelse, nedværdigelse, trussel e.a., yder stærkere beskyttelse af persongrupper af denne karakter. Således ligestilles enkeltindivider med grupper af mennesker. For det andet indebar ændringen tilsvarende strafbeskyttelse mod diskrimination, som består i forfølgelse på grund af seksualitetens art. I det forberedende lovarbejde blev der set på § $266 \mathrm{~b}$ i den danske straffelov og § 135 a i den norske straffelov.

\section{Hvidvask af udbytte ved overtrcedelse af straffeloven}

På grund af Islands ratifikation af De forenede Nationers konvention mod ulovlig handel med narkotika og euforiserende stoffer af 20. december 1988 og ratifikationen af Europarådets konvention om hvidvask, eftersøgning, besiddelse og konfiskation af udbytte fra 8. november $1990 \mathrm{blev}$ det anset for nødvendigt at foretage ændringer i straffeloven, jf. lov nr.10/1997.

Islandsk straffemyndighed blev udvidet med en tilføjelse til bestemmelsen i straffelovens $\S 4$ om straffemyndighed baseret på territorialprincippet. Overtrædelse af straffelovens $§ 264$ (se i det følgende) kan derfor straffes i medfør af den islandske straffelov, hvis overtrædelsen sker inden for den islandske stat, selvom den forbrydelse, hvorfra udbyttet stammer, er blevet begået i udlandet og uden hensyn til gerningsmandens identitet. Til straffelovens $\S 69$, stk. 3 om konfiskation blev føjet, at det nu er tilladt at konfiskere ting, der er købt for udbytte som nævnt ovenfor, og dommeren har desuden hjemmel til at skønne om udbyttets værdi, hvis denne ikke kan bevises. Bestemmelsen i straffelovens $\S 173 \mathrm{~b}$ om hvidvask i forbindelse med narkotikaforbrydelser blev taget ud og erstattet af en ny bestemmelse, straffelovens $\S 264$. Hvidvask af udbytte ved overtrædelser af straffeloven er nu en selvstændigt strafbar lovovertrædelse uden hensyntagen til, hvilken førforbrydelse udbyttet stammer fra. Overtrædelsen straffes med bøde eller fængsel i op til 2 år. Hvis det drejer sig om en gentagen eller grov handling, kan straffen stige op til 4 års fængsel. Hvis lovovertrædelsen begås uagtsomt, straffes den med bøde eller fængsel op til 6 måneder. Hvis den forbrydelse, som udbyttet stammer fra, ikke kan straffes med strengere straf end op til 1 års fængsel, kan straf for hvidvaskning bortfalde. En særlig regel gælder om straf angående hvidvask af udbytte fra en grov narkotika- 
forbrydelse jf. straffelovens $\S 173 \mathrm{a}$, men sådanne forbrydelser kan også straffes med op til 10 års fængsel. Ved lovforberedelsen blev der taget hensyn til den norske straffelovs $\S 317$ og $\S \S 6-7$, kap. 9 , i den svenske brottsbalk.

\section{Dataforbrydelser}

Med lov nr. 30/1998 blev der foretaget forskellige ændringer i straffeloven, der sigter mod at straffe nærmere bestemte handlinger, som er knyttet til computere og disses anvendelse. I lovforslaget anvendes begrebet dataforbrydelse som en fællesbetegnelse for forskellige typer retsstridige handlinger, der begås ved at bruge computer eller retter sig imod computere, software eller mod oplysninger, der opbevares i computere eller i maskinlæsbar form.

Lovændringen kan deles op i følgende tre kategorier: For det første forbrydelser begået ved brug af computer. I den forbindelse blev der føjet en ny bestemmelse til straffeloven, § 249 a. Ifølge bestemmelsen er det strafbart, hvis man på en retsstridig måde ændrer, tilføjer eller ødelægger hardware eller data eller programmer, der opbevares i maskinlæsbar form, eller på anden måde gør foranstaltninger til at påvirke resultaterne af databehandling. Bestemmelsen omfatter alle handlinger, der kan påvirke resultaterne af databehandling, hvad enten de sigter mod data eller programmer, der opbevares i maskinlæsbar form eller mod selve hardwaren. Under bestemmelsens gerningsindhold falder endvidere dispositioner, der medvirker til, at forkerte oplysninger indføres i computere, og som senere kan bevirke den tilsigtede pengeoverførsel. Straffen for overtrædelsen er op til 6 års fængsel. Endvidere blev der føjet nye stykker til $\S § 155,157$ og 158 om dokumentforbrydelser. Det blev anset for nødvendigt også at lade bestemmelserne omfatte dokumenter, der opbevares i maskinlæsbar form, da de ikke hidtil er blevet anset for at være omfattet af den traditionelle opfattelse af dokumentbegrebet, som forudsætter, at det drejer sig om skriftlige dokumenter. Med maskinlæsbar form menes, at dokumenter (eller programmer) opbevares i den form og med symboler, så at de kan aflæses i computere fx plader, disketter, bånd, cd'er o.s.v.

For det andet blev der indsat en bestemmelse om hærværk mod computere ved at føje et nyt afsnit til straffelovens $\S 257$, stk. 1, om tingsødelæggelse. Det fremgår heraf, at det er strafbart at ændre, tilføje, slette og på anden måde uden hjemmel ødelægge dokumenter eller programmer, der opbevares i maskinlæsbar form og er bestemt til databehandling. Bestemmelsen udstrækker sig således over hærværk på computer-hardware til hærværk, der udøves på en "databærer", der indeholder programmer eller dokumenter, og til sletning eller ændring af programmer eller dokumenter, hvor der ikke samtidig er tale om ødelæggelse af computer eller "databærer". Under bestemmelsen falder endvidere ændringer af dokumenter eller programmer, der består i at anbringelse af de såkaldte computerviruser, der kan medføre forstyrrelser i databehandlingen eller ødelæggelse af dokumenter eller programmer.

For det tredje blev der indsat bestemmelser om indbrud i computersystemer. Der blev føjet et nyt afsnit til straffelovens $\S 228$, stk.1, om brevhemmeligheden, hvor det beskrives som strafbart på en retsstridig måde at skaffe sig adgang til andres dokumenter eller programmer, der opbevares maskinelt. Hensigten med denne tilføjelse er at nå de dataforbrydelser, hvor formålet ikke er at kigge i bestemte dokumenter, men hvor indbruddet i sig selv er målet. Med ordlyden "på retsstridig måde" menes, at adgangen sker uden tilladelse. Ved lovforberedelsen blev der bl.a. set på det danske straffelovråds betænkning nr. 1032/1985 om dataforbrydelser.

\section{En sarlig regel om foraldelse af skyld i forbindelse med seksualforbrydelser mod børn}

Med lov nr. 63/1998 blev der foretaget ændringer i straffelovens regler om forældelse af skyld m.v. De vigtigste nyheder bestod $\mathrm{i}$ ændringer af reglerne om forældelse af skyld i forbindelse med seksualforbrydelser mod børn. Ifølge straffelovens $\S 82$, stk. 1, begynder forældelsesfristen for seksualforbrydelser mod børn nu ikke at løbe, før den dag offeret fylder 14 år. Forældelsesfristen løber i øvrigt fra den dag, den strafbare handling sluttede, medmindre offeret på det tidspunkt ikke havde nået førnævnte alder. I det tilfælde løber fristen fra den dag, hvor offeret når den nævnte alder. Fristens begyndelse regnes fra det senere tidspunkt. Hvis handlingen strækker sig ud over 14-års grænsen eller begynder, efter at offeret er fyldt 14 år, regnes fristen fra den dag, hvor handlingen sluttede. 
Formålet med ændringen er at tilpasse straffelovens forældelsesregler til de situationer, der kan opstå, når børn bliver ofre for seksualforbrydelser. Der er ellers fare for, at forældelsesfristen er udløbet, når barnet har nået den nødvendige modningsgrad for at kunne gøre sig den strafbare handling klar. Der er endvidere fare for, at børn har begrænsede muligheder for at anmelde sådanne forbrydelser. Anledningen til ændringen har bl.a. rod i Børnenes Ombudsmands note til Justitsministeren af september 1997 angående seksualforbrydelser mod børn.

\section{Afskaffelse af haftestraf}

Med lov nr. 82/1998 blev hæfte afskaffet som en form for frihedsstraf. Om grundene til denne ændring kan bl.a. nævnes, at hæfte siden straffelovens vedtagelse i 1940 ikke har opnået den særstilling m.h.t. længde og indhold, som loven tilstræbte. Hvad angår længden i tid, så overlappede strafferammerne for hæfte og fængsel normalt hinanden i lovgivning og retspraksis. Selvom fængsel oprindeligt var ment som en hårdere straf end hæfte, var straffenes indhold i virkeligheden det samme, idet de faktiske afsoningsforhold i İsland hele tiden har været således, at det ikke har været muligt at fuldbyrde straffen i overensstemmelse med de forskellige regler, der gjaldt for fængsel og hæfte. Endvidere ændredes behandlingen af fanger under afsoning i tidens løb så småt i retning af de regler, som gjaldt for hæftefanger ifølge loven. Med den gældende lov om fængsler og fængselsophold nr. 48/1988 blev den samme retsstilling for hæftefanger og fængselsfanger lovfæstet.

Ved afskaffelsen af hæftestraffen blev det nødvendigt at foretage forskellige ændringer i straffeloven og i straffebestemmelser i andre love. I straffelovens almindelige del i kap. I-IX, der angår alle strafbare lovovertrædelser, blev bestemmelserne om hæftestraf afskaffet, således at straf ifølge loven nu er fængsel og bøde. Selv om hæftestraffen blev afskaffet, blev der ikke foretaget ændringer i fængselsstraffens minimum på 30 dage, jf. straffelovens $\S 34$, stk. 1 . I de bestemmelser i straffeloven, hvor straffen var bøde, hæfte eller fængsel enten i 3 eller 6 måneder eller i 1 år, blev strafferammen ændret, således at hæfte blev afskaffet, uden at der blev rokket ved fængselsstraffen. I nogle af straffelovens bestemmelser var straffen for overtrædelse bøde eller hæfte $\mathrm{i}$ en bestemt periode, enten 3 eller 6 måneder eller 1 år. Disse bestemmelser blev ændret, således at fængsel sattes i stedet for hæfte uden tidsmæssige ændringer. I adskillige af straffelovens bestemmelser var straffen for overtrædelse bøde eller hæfte uden tidsbegrænsning af hæftestraffens længde. Derfor kunne hæfte højest blive 2 år, jf. det almindelige maksimum i straffelovens $\S 44$. Under hensyn til den indbyrdes overensstemmelse og til overtrædelsernes karakter, anså man det ikke for hensigtsmæssigt at lade 2 års fængselsstraf erstatte hæfte i alle tilfælde. Derfor valgte man i de fleste tilfælde den udvej at erstatte hæfte med fængsel i op til 1 år, men i enkelte tilfælde anså man ikke dette for hensigtsmæssigt. I de tilfælde blev fængselsstraffens længde efter omstændighederne fastsat til enten 3 eller 6 måneder.

På grund af afskaffelsen af hæftestraffen blev der foretaget omfattende ændringer i straffebestemmelserne i andre love end straffeloven. I særlovgivningen har det været almindeligt at straffen for overtrædelse var bøde eller hæfte uden begrænsninger i hæftestraffens længde. Hæfte kunne derfor højest blive 2 år. Disse bestemmelser blev ændret, således at 2 års fængsel nu erstatter hæfte. I nogle tilfælde fraveg man dog dette med kortere fængselsstraf. Der blev i øvrigt foretaget ændringer i særlovgivningens straffebestemmelser svarende til straffelovens.

\section{Strafansvar for juridiske personer}

Med lov nr. 140/1998 blev der indføjet bestemmelser i straffeloven om strafansvar for juridiske personer. På grund af den særlige karakter som strafansvar for juridiske personer har, samt det forhold, at straffeloven ikke i øvrigt omhandler ansvar af den karakter, blev der føjet et nyt afsnit til straffeloven, kap. II. A. Ifølge § $19 \mathrm{a}$ kan en juridisk person straffes med bøde, når det er bestemt ved lov. Bestemmelsen indebærer ikke en selvstændig straffehjemmel, men fastsætter på den anden side som almindelig forudsætning for juridiske personers strafansvar, at der i særlovgivningen findes hjemmel til at straffe juridiske personer. Ordlyden indebærer, at juridiske personer ikke forudsættes at være strafansvarlige på samme måde som enkeltpersoner. Ifølge $\S 19 \mathrm{~b}$ gælder bestemmelserne om strafansvar for juridiske personer, med mindre andet er fastsat, for enhver ikke-menneskelig part, der kan have rettigheder og bære pligter efter islandsk lov, derunder aktie-, anparts- og kommandit- 
selskaber, europæiske økonomiske firmagrupper, interessentskaber, andelsselskaber, ideelle foreninger, selvejende institutioner, statslige myndigheder, institutioner og kommuner. Af $\S 19 \mathrm{c}$ fremgår, at juridiske personers strafansvar, medmindre andet fremgår af loven, forudsætter, at repræsentanten for den juridiske person, hans ansatte eller en anden person på hans vegne på retsstridig måde har begået en strafbar og ulovlig handling i den juridiske persons virksomhed. Om statslige myndigheders strafansvar er fastsat, at det er en forudsætning for dette ansvar, at der er begået en retsstridig og strafbar handling $i$ en virksomhed, der kan sammenlignes med enkeltpersoners virksomhed.

Desuden blev der foretaget ændringer i strafbestemmelserne i straffelovens $\S \S 51,52$ og 53. Den vigtigste ændring er, at forvandlingsstraf ikke fastsættes, når en juridisk person idømmes bøde. Desuden blev der føjet to nye afsnit til forældelsesbestemmelsen i straffelovens $\S 82$, stk. 4 , om, at i tilfælde af afbrydelse af forældelsesfristen over for nogen, der handler på den juridiske persons vegne, hans ansatte eller andre på hans vegne, har fristafbrydelsen også virkning i forhold til den pågældende juridiske person. Afbrydelse af forældelsesfristen over for den juridiske person medfører derimod ikke fristafbrydelse i forhold til repræsentanter for den juridiske person, ansatte eller andre, der har handlet på dennes vegne.

\section{Bestikkelse af udenlandsk offentligt ansat}

I december 1997 underskrev islandske myndigheder OECDs konvention om kampen mod bestikkelse af udenlandske offentligt ansatte $i$ international handel af 21. november 1997. For at kunne opfylde konventionens betingelser blev der ved lov nr. 147/1998 foretaget ændringer i straffelovens $\S 6$ og $\S 109$. Til straffelovens $\S 6$ blev føjet et nyt nr. 10 om, at det islandske realprincip omfatter de handlinger, som konventionen indeholder. Et nyt stk. 2 blev føjet til straffelovens $\S 109$ om idømmelse af op til 3 års fængselsstraf eller under formildende omstændigheder bøde for at give, love eller tilbyde en udenlandsk offentligt ansat eller en offentlig international institutions ansatte en gave eller anden gevinst i det øjemed at opnå eller fastholde handel eller en anden utilbørlig gevinst i internationale forretninger.

Det blev i loven endvidere anset for nødvendigt at placere ansvar hos juridiske personer for deres ansattes bestikkelse af udenlandske offentligt ansatte, og i den forbindelse blev lov nr. 144/1998 om juridiske personers strafansvar på grund af bestikkelse af en offentligt ansat vedtaget. Den juridiske person pålægges strafansvar, hvad enten bestikkelsen tilbydes en indenlandsk eller udenlandsk offentligt ansat eller en offentlig international institutions ansat.

\section{Prøveløsladelse}

Med lov nr. 24/1999 blev der foretaget ændringer i straffelovens $\S \S 40-42$ og $\S \S 58-60$. Betingelsen om en minimumsgrænse i straffetiden før prøveløsladelse blev fjernet fra straffeloven, således at der nu prøveløslades, selvom den resterende fængselsstraf er under 30 dage. Prøveløsladelse gives ikke, hvis en del af fængselsstraffen er betinget Hermed har man i loven indført en anvendt forvaltningspraksis, der er baseret på en bekendtgørelse om fuldbyrdelse af straffedomme fra året 1993. Prøveløsladelse gives heller ikke, når bødeforvandlingsstraffe afsones. Endvidere blev der fra loven fjernet en hjemmel til den administrative myndighed til at træffe beslutning om afsoning af reststraffen i tilfælde af, at prøveløsladelsens vilkår overtrædes med uomtvistelig ny kriminalitet til følge. I stedet skal man afvente domstolens vurdering af den seneste lovovertrædelse, eftersom straffen bestemmes samtidig for den seneste lovovertrædelse og for en uafsonet reststraf af fængsel hidrørende fra en tidligere dom.

\section{Miljøforbrydelser}

Med lov nr. 122/1999 blev der indsat en bestemmelse i straffelovens $\S 179$ om miljøforbrydelser. Der står, at nærmere omtalte overtrædelser af love om værn af miljøet straffes med op til fire års fængsel. Det drejer sig om grove overtrædelser af disse love, der indebærer forurening af luft, jord, hav eller vandområder, samt opbevaring eller dumpning af affald eller skadelige stoffer med den følge, at der sker betydelig skade på miljøet. Bestemmelsen omfatter også forvoldelse af overhængende fare for førnævnte skader og omfattende jordombrydning, således at landet permanent ændrer 
udseende, og endelig ødelæggelse af værdifulde naturmonumenter. Ved udformningen af loven toges hensyn til den danske straffelovs $§ 196$ og den norske straffelovs $\S 152 \mathrm{~b}$.

\section{Endringer i retsplejeloven 19/1991 fra 1994}

\section{Endringer $i$ anklagemyndighedens organisation}

Med lov nr. 84/1996 blev der foretaget nogle ændringer af bestemmelserne i retsplejeloven angående anklagemyndighedens organisation, en ændring der blev lavet samtidig med vedtagelsen af en ny politilov nr. 90/1996, der omtales i det følgende. De vigtigste nyheder i lov nr. 84/1996 er følgende: For det første er politimestrene, derunder Rigspolitimesteren, i deres egenskab af anklagemyndighed blevet sidestillet med Rigsadvokaten i stedet for som tidligere, at politimestrene var underlagt Rigsadvokatens almindelige instruktionsbeføjelse under udøvelsen af anklagemyndighed. For det andet får Justitsministeren hjemmel til at ansætte anklagere ved de enkelte politimesterembeder, derunder Rigspolitimesterembedet, med henblik på at varetage tiltale og retsforhandlinger på politimesterens vegne. For det tredje er Rigsadvokatens og politimesterens anklagemyndighed defineret på ny, således at Rigsadvokatens anklagemyndighed defineres positivt og politimesterens anklagemyndighed definieres negativt. Det indebærer, at Rigsadvokaten ifølge loven skal føre offentlige sager for overtrædelse af de fleste og groveste bestemmelser i straffeloven, herunder landsforræderi, grove narkotikaforbrydelser, drab, grove legemsangreb, seksualforbrydelser, røveri og afpresning. Det er omvendt overdraget politimestrene, dermed også Rigspolitimesteren, at anlægge andre offentlige sager end dem, som Rigsadvokaten fører. Undtaget Rigsadvokatens anklagemyndighed er overtrædelser af 17 bestemmelser i straffeloven, derunder de hyppigste overtrædelser såsom dokumentfalsk, mindre legemsangreb, husfredskrænkelse, tyveri, underslæb, bedrageri, tingsødelæggelse og brugstyveri. For det fjerde har politimestrene, dermed også Rigspolitimesteren, fået ret til at meddele tiltalefrafald med kæreadgang til Rigsadvokaten. Rigsadvokaten kan endvidere på eget initiativ tage en sådan beslutning op til revision og beslutte at anlægge en sag eller pålægge en politimester eller Rigspolitimesteren at rejse sag.

\section{Anholdte personers retsstilling}

Ved lov nr. 136/1996 blev der foretaget visse ændringer af reglerne i retsplejeloven vedrørende anholdte personers retsstilling. For det første blev der tilføjet to nye afsnit til lovens $\S 32$, stk.1, som omhandlede udsættelse med at give nærmeste pårørende underretning om anholdelse med den begrundelse, at det ville vanskeliggøre sagens efterforskning. I sådanne tilfælde skal politiet så hurtigt som muligt efter anholdelsen give nærmeste pårørende meddelelse om herom og om, hvor den sigtede blev anbragt. Justitsministeren fastsætter ved bekendtgørelse nærmere bestemmelser om, hvornår det er tilladt at nægte en anholdt person at kontakte sine nærmeste pårørende. For det andet blev der føjet et nyt stykke til retsplejelovens $\S 69$ med hjemmel til, at Justitsministeren ved bekendtgørelse fastsætter nærmere bestemmelser om proceduren for afhøringer. For det tredje blev der tilføjet et nyt stykke til retsplejelovens $\S 101 \mathrm{om}$, at Justitsministeren ved bekendtgørelse fastsætter bestemmelser om anbringelse af anholdte personer. For det fjerde blev der føjet et nyt stykke til retsplejelovens $\S 108$ med adgang for varetægtsfanger til at modtage og sende breve til domstolene, Justitsministeren, Altingets ombudsmand og forsvareren uden, at indholdet kan undergives ransagning. Endvidere fik Justitsministeren hjemmel til at udsende bestemmelser om, at varetægtsfanger kan sende andre offentlige instanser eller privatpersoner breve uden undersøgelse af indholdet.

\section{Effektivere behandling af mindre bødesager}

Med lov nr. 31/1998 blev der vedtaget en ny bestemmelse i retsplejelovens $\S 115 \mathrm{a}$, hvis formål er at gøre behandlingen af mindre bødesager mere effektiv og målrettet og dermed at opnå et forbedret resultat i forbindelse med inddrivelse af bøder. Politimesteren kan give den sigtede mulighed for at afslutte mindre sager mod betaling af bøde. Den sigtedes passivitet med hensyn til politimesterens bødeforelæg og manglende fremsættelse af eventuelle indsigelser bestyrker i almindelighed sand- 
synligheden for den sigtedes skyld, hvis sagens øvrige oplysninger peger i samme retning. Dommeren fastsætter i så tilfælde bøden og forvandlingsstraffen ved påtegning af politimesterens bødeforelæg. Påtegning af bødeforelæg har samme gyldighed som en dom, og det er derfor muligt at inddrive bøden ved udlæg eller at benytte forvandlingsstraf.

Forudsætningen for, at en sag kan afsluttes på den måde, er, at visse betingelser bliver opfyldt. For det første skal politimesteren besidde anklagemyndigheden i sagen ifølge retsplejelovens $\S 28$. For det andet må sanktionen ikke overstige bøde på $50.000 \mathrm{IKK}$. For det tredje må der ikke være tillægssanktioner ud over bøden, f.eks. rettighedstab eller konfiskation, og for det fjerde skal den sigtede eller den, som på den sigtedes vegne kan modtage forkyndelse af stævning $\mathrm{i}$ en civil sag, bevisligt have modtaget politimesterens bødeforelæg uden at reagere på det inden for 30 dage. Efter bødeforelæggets påtegnelse kan den sigtede kræve, at sagen genoptages under henvisning til, at han kan fremføre et forsvar, der vil kunne påvirke sagens udfald. Der regnes med, at den sigtede har gode muligheder for at få en sag genoptaget, således at anmodningen kun vil blive afvist $\mathrm{i}$ helt grundløse tilfælde. Anmodning om genoptagelse skal rettes til den domstol, der behandlede sagen inden for fire uger efter, at den sigtede fik underretning om bødeforelægget. Sagen afgøres ved kendelse, som kan kæres til Islands Højesteret, jf. retsplejelovens § 142, stk.1.

\section{Ofrenes retsstilling m.m.}

Ved lov nr. 36/1999 blev retsplejeloven ændret med henblik på at styrke ofrenes retsstilling, især f.s.v. angår voldsofre. Herudover blev loven ændret på flere andre punkter. Ved udarbejdelsen af den del af loven, der behandler ofrenes retsstilling, toges der især hensyn til forslag fra Børnenes Ombudsmand, samt til de fremsatte forslag i en betænkning fra et ministerudvalg, som var nedsat med henblik at undersøge ofrenes retsstilling og komme med forslag til forbedringer. Desuden så man på ofrenes retsstilling i nordisk retspleje i øvrigt, især dansk og norsk lovgivning.

Hovedændringen i ofrenes retsstilling i retsplejelovens kap. VII er, at det nu er påbudt at udnævne en talsmand for offeret efter dettes eller værgens ønske for at varetage offerets interesser, hvis efterforskningen i sagen angår bestemte alvorlige forbrydelser, og det formodes, at offeret har lidt alvorlig skade af den grund og behøver særlig bistand. Når det drejer sig om børn under 18 år, går man endnu længere, hvis der hersker mistanke om, at de har været offer for en seksualforbrydelse, i hvilket tilfælde en talsmand under alle omstændigheder er påkrævet. Ellers er foreskrives udnævnelse af en talsmand for ofre for seksualforbrydelser, hvis det ønskes. Andre vigtige lovændringer af offerets retsstilling er følgende: For det første blev bestemmelserne om lukkede retsmøder ændret, så at offeret nu kan kræve retsmødet lukket med kæreadgang til Højesteret. For det andet indføres bedre adgang til at sikre hemmeligholdelse af oplysninger om offerets personlige forhold. Hvis der er særlig anledning, skal oplysninger, som det er naturligt at hemmeligholde af hensyn til almene eller private interesser, slettes i de udskrifter af retsbog og domsregister, der udleveres til andre end sagens parter og offeret selv. For det tredje har politiet pligt til at vejlede offeret om dettes lovmæssige rettigheder. Desuden er bestemmelserne om politiets og anklagerens oplysningspligt overfor offeret blevet udbygget. For det fjerde er det i forbindelse med efterforskningen af seksualforbrydelser, hvor offeret er et barn under 18 år, blevet bestemt, at en dommer skal afhøre barnet hurtigst muligt, d.v.s. inden tiltale rejses, og endvidere at barnet som regel ikke behøver at blive afhørt i sagen påny. Endelig gælder det for det femte ved afhøring af et offer under 18 år, at anklageren, den sigtede og forsvareren ikke har en absolut ret til at være til stede i retten eller uden for retten, hvor afhøringen foregår, men de skal have mulighed for at følge med i afhøringen samtidig med, at den foregår.

Der blev foretaget forskellige andre mindre ændringer i loven. De vigtigste ændringer er følgende: Ifølge Bestemmelsen i retsplejelovens $\S 43$ har forsvareren nu uhindret adgang til at gøre den sigtede bekendt med sagens dokumenter, så snart han har fået dem i sin besiddelse. Derimod kan politiet nægte at give forsvareren adgang til undersøgelsesmateriale i op til én uge efter modtagelsen, hvis det antages, at det kan skade efterforskningen. I den periode kan politiet fremsætte ønske om, at den sigtede eller vidner afhøres i retten for at få sagen opklaret, inden den sigtede får mulighed for at konferere med andre. I den forbindelse blev der indsat en ny bestemmelse i retsplejeloven, $§ 74 \mathrm{a}$. Et 
nyt stykke blev føjet til retsplejelovens $\S 49$ med adgang til at afhøre et vidne gennem telefon eller ved hjælp af anden fjernkommunikation i straffesager på samme måde som i civile sager. Et nyt stykke blev føjet til retsplejelovens $\S 66$ med speciel hjemmel til Rigsadvokaten om at sætte efterforskning i gang, selv om det formodes, at den pågældende ikke kan straffes, fx p.g.a. forældelse af strafansvar eller under henvisning til vigtige almene eller private interesser. Bestemmelsen i retsplejelovens $\S 87$, stk. 1, blev ændret, så at det nu ikke længere er tilstrækkeligt at få ejerens eller en aktuel brugers samtykke til aflytning af telefonsamtaler i forbindelse med efterforskningen i en straffesag; der behøves nu altid en dommerkendelse. Reglerne om sagsomkostninger blev ændret i retsplejelovens $\S \S 164,167-169$, bl.a. bliver omkostninger i forbindelse med gennemførelse af straffesagen for statens vedkommende ikke henregnet til sagsomkostningerne. Der blev foretaget en ændring i retsplejelovens $\S 175$, stk. 1, og $\S 177$ i overensstemmelse med forfatningslovændringer i 1995, således at det nu ikke længere er en betingelse for erstatning til en person, der har udstået frihedsstraf eller været genstand for tvangsindgreb som fx varetægtsfængsling uden at været blevet fundet skyldig i en strafbar handling, at formodningen for uskyld overvejer formodningen om skyld. Endelig blev der foretaget ændring i retsplejelovens $\S 184$, stk. 1, om hjemmel for genoptagelse af sag med henblik på at genvurdere beviserne i sagen.

\section{Ny lov om politianliggender nr. 90/1996}

Politilov nr. 90/1996 trådte i kraft den 1. juli 1997, hvorved lov om politiet 56/1972 med senere ændringer og lov om Statens kriminalpoliti 108/1976 med senere ændringer blev ophævet. Ved affattelsen af loven tog man hensyn til lovgivningen i de øvrige nordiske lande, især norsk og finsk lovgivning fra 1995. Loven er delt op i ti kapitler, hvor de vigtigste nyheder er følgende: For det første defineres begreberne politi, politiets rolle og håndhævelse af politimyndighed. For det andet blev der gjort den grundlæggende ændring i politiets organisation og øverste myndighed, at Rigspolitimesterembedet blev oprettet. Rigspolitimesteren forvalter det islandske politi på vegne af Justitsministeren, og embedet overtog en række opgaver, der tidligere hørte under Justitsministeriet, Statens kriminalpoliti og politimesteren i Reykjavík. Under Rigspolitimesterembedet hører ligeledes specielle efterforskningsafdelinger, men embedets efterforskningsmæssige opgaver er dog mindre omfattende end dem, som tidligere tilkom Statens kriminalpoliti. Størstedelen af Statens kriminalpolitis politiefterforskningsopgaver blev overført til politimesterembederne i de enkelte distrikter, men efterforskning inden for skatte- og økonomisk kriminalitet blev flyttet til Rigspolitimesteren, hvor der også findes støtteafdelinger, som kan yde assistance til enkelte politimesterembeder ved efterforskningen af svære kriminelle sager, samt et laboratorium til at foretage tekniske undersøgelser af dokumenter, fingeraftryk m.v. Politimesteren i Reykjavík skal derimod, foruden at drive de almindelige efterforskningsenheder i sit distrikt, drive en teknisk afdeling, der skal betjene hele landet med henblik på at varetage eller assistere ved efterforskning på gerningsstedet, samt ved andre lignende efterforskninger. For det tredje blev der vedtaget bestemmelser om politiets arbejdsområde, derunder en hjemmel til Justitsministeren til at beslutte, at en del af politistyrken skal varetage politiopgaver i hele landet. For det fjerde blev indført bestemmelser om politiets arbejdspligter, magtudøvelse og anholdelse, adgang til at visitere personer og udøve anden kontrol med borgerne i form af en generalfuldmagt. For det femte blev der indført en særlig bestemmelse om tavshedspligt for politiets ansatte og bestemmelser om politiets bijob. For det sjette indførtes der regler om behandling af klager mod politiet vedrørende ulovlig udførelse af politimyndighed; sådanne klager henvises til Rigsadvokaten, der skal behandle sagen. Til syvende og sidst blev der ændret i Statens politiskoles struktur, således at skolen nu anses for at være en selvstændig institution. Rigspolitimesteren afgør hvert år, hvor mange elever der skal optages og annoncerer efter elever til skolen over hele landet. Skolens optagelseskriterier er lovfæstede og et særligt forvaltningsudvalg, optagelsesudvalget, udvælger eleverne. Det første af skolens tre semestre er ulønnet, og politieleverne anses ikke for at være politifolk før efter afslutningen af det første semester. 


\section{Fndringer i lov om fængsler og fængselsophold 48/1988, fra1994}

\section{Samfundstjeneste}

Med lov nr. 123/1997 blev der indsat bestemmelser om samfundstjeneste i lov om fængsler og fængselsophold 48/1988, idet en midlertidig lov om samfundstjeneste ophævedes. Man fandt det naturligt at placere bestemmelserne om samfundstjeneste i loven om fængsler og fængselsophold, eftersom samfundstjeneste retligt anses for at være en måde at fuldbyrde ubetinget frihedsstraf på. Meningen var, at udførelse af samfundstjeneste i højere grad skulle tilpasses straffuldbyrdelsens øvrige elementer. Med loven blev adgangen til straffuldbyrdelse i form af samfundstjeneste udvidet, således at det nu er muligt at fuldbyrde helt op til 6 måneders ubetinget frihedsstraf ved udførelse af samfundstjeneste mod tidligere 3 måneder. Det er Statens Fængselsdirektorat, der afgør sager om samfundstjeneste i stedet for det tidligere, særligt nedsatte samfundstjenesteudvalg. Statens Fængselsdirektorats afgørelser kan appelleres til Justitsministeren, der tager den endelige beslutning om sagens ekspedition efter høring af benådningsudvalget. Overtrædelser af vilkårene for samfundstjeneste behandles efter tilsvarende regler som for disciplinærstraffe i fængsler i stedet for som tidligere som vilkårsovertrædelse for prøveløsladelse. Til slut blev det som noget nyt indført, at der er adgang til prøveløsladelse, hvis en del af frihedsstraffen er blevet fuldbyrdet med samfundstjeneste.

\section{Afsoning af straf uden for fcengslet og fuldbyrdelse af forvandlingsstraf med samfundstjeneste}

Med lov nr. 22/1999 blev der indført bestemmelser i loven om fængsler og fængselsophold om afsoning af straf udenfor fængslet og fuldbyrdelse af forvandlingsstraf med samfundstjeneste. Angående det førstnævnte blev der tilføjet et nyt stykke til $§ 11 \mathrm{i}$ lov om fængsler og fængselsophold, hvis indhold er, at Statens Fængselsdirektorat kan give en fange mulighed for at afslutte afsoning udenfor fængslet, såfremt han udfører et arbejde eller er under uddannelse, som Statens Fængselsdirektorat har godkendt, bor på en særlig institution eller i et hjem, hvor han er under opsyn. Arbejdet eller uddannelsen skal udgøre en del i den pågældendes gentilpasning til samfundet. Endvidere skal fangen betale de opholdsudfgifter, som sådanne institutioner eller hjem opkræver hos de logerende. Denne lovændring er et led i en udvikling hen imod at lovfæstelse af en vellykket forvaltningspraksis, idet Statens Fængselsdirektorat over en periode har givet fanger tilladelse til at afslutte afsoningen med ophold på Vernds etapehjem ("Beskyttelse", en forening der har hjulpet fanger i snart 40 år), såfremt de udfører et arbejde eller er under en form for uddannelse, som direktoratet anerkender. Forvaltningspraksisen hvilede på $§ 11 \mathrm{i}$ lov om fængsler og fængselsophold, ifølge hvilken der er hjemmel til at indsætte domfældte personer på et sygehus eller en anden institution, hvor vedkommende får særlig behandling eller omsorg, hvis vedkommendes helbred, alder eller andre særlige omstændigheder nødvendiggør dette. Knap 18\% af dem, der afsluttede afsoningen i perioden 19951998, fik mulighed for at afsone hos Vernd. Det var hver fjerde fange i 1998.

Et nyt kapitel om fuldbyrdelse af forvandlingsstraf med samfundstjeneste blev føjet til loven om fængsler og fængselsophold. Hvis en bøde ikke kan inddrives, og politimesteren har besluttet, at en person skal afsone en forvandlingsstraf, er der, hvis det ikke strider mod almene interesser, hjemmel til at fuldbyrde forvandlingsstraffen med ulønnet samfundstjeneste, mindst 20 timer og højest 480 timer. Vilkårene for den måde at afsone forvandlingsstraf på er de samme, som gælder samfundstjeneste i øvrigt.

\section{Statistiske oplysninger om fuldbyrdelse af straffedomme}

I Statens Fængselsdirektorats rapporter gives statistiske oplysninger vedrørende fuldbyrdelse af domme og om dømte i de forudgående 5 år. I det følgende redegøres der for enkelte træk af denne statistik. 
De straffe, som Fængselsdirektoratet fik tilsendt til fuldbyrdelse i 1994-1999, fordeler sig således efter art:

\begin{tabular}{lrrrrrr} 
& $\mathbf{1 9 9 4}$ & $\mathbf{1 9 9 5}$ & $\mathbf{1 9 9 6}$ & $\mathbf{1 9 9 7}$ & $\mathbf{1 9 9 8}$ & $\mathbf{1 9 9 9}$ \\
\hline Ubetinget frihedsstraf+ evt. andet & 449 & 378 & 360 & 301 & 305 & 258 \\
Betinget frihedsstraf + evt. bøde & 380 & 332 & 332 & 358 & 420 & 374 \\
Bet. udsættelse af straffastsæt. & 41 & 41 & 34 & 35 & 61 & 50 \\
Bet. udsæt. af straffasts. + bøde & 0 & 0 & 0 & 3 & 1 & 1 \\
Bødedomme & 451 & 554 & 483 & 441 & 627 & 617 \\
Betingede bødedomme & 0 & 0 & 0 & 0 & 3 & 1 \\
\hline I alt antal dømte & 1321 & 1305 & 1209 & 1138 & 1417 & 1301 \\
& & & & & & \\
Antal bødestraffe ifølge sanktionsfastsættelse & 617 & 699 & 502 & 408 & 568 \\
Antal bødestraffe ifølge påtegnet bødeforelæg & & & & 1753 & 1504
\end{tabular}

Det bør understreges, at disse tal ikke indeholder oplysninger om antallet af afsagte domme; tallene er udtryk for de domme, som Fængselsdirektoratet fik tilsendt til fuldbyrdelse i perioden. Tabellen viser, at antallet af domfældte faldt i perioden helt op til 1998, men derefter steg antallet betydeligt. Den stigning kan hovedsagelig forklares med stigning i betingede straffedomme og bødestraffe. Med lov nr. 31/1998 skete den ændring i retsplejeloven, som muliggør afslutning af mindre lovovertrædelser med en dommertilkendegivelse om bødestraf og forvandlingsstraf, som sker ved dommerpåtegning på politimesterens bødeforelæg som nævnt i kapitel III 3. Således påtegnede bødeforelæg, 1753 stykker, fik Fængselsdirektoratet tilsendt fra den 7. oktober til årsskiftet og 5104 i 1999.

Antallet af ubetingede frihedsstraffe, som direktoratet fik tilsendt til fuldbyrdelse, fordeler sig således i forhold til frihedstraffens længde:

\begin{tabular}{lcrrrrr} 
& $\mathbf{1 9 9 4}$ & $\mathbf{1 9 9 5}$ & $\mathbf{1 9 9 6}$ & $\mathbf{1 9 9 7}$ & $\mathbf{1 9 9 8}$ & $\mathbf{1 9 9 9}$ \\
\hline 30 dage og mindre & $21,2 \%$ & $24,6 \%$ & $20,6 \%$ & $24,3 \%$ & $22,3 \%$ & $20,5 \%$ \\
mere end 30 dage til og med 3 mdr. & $37,6 \%$ & $35,7 \%$ & $36,7 \%$ & $30,9 \%$ & $39,7 \%$ & $40,7 \%$ \\
mere end 3 mdr. til og med 6 mdr. & $16,0 \%$ & $16,7 \%$ & $18,6 \%$ & $15,0 \%$ & $14,1 \%$ & $14,7 \%$ \\
mere end 6 mdr. til og med 12 mdr. & $15,6 \%$ & $13,8 \%$ & $11,9 \%$ & $16,3 \%$ & $12,1 \%$ & $10,9 \%$ \\
mere end 12 mdr. til og med 36 mdr. & $8,9 \%$ & $8,7 \%$ & $11,1 \%$ & $9,6 \%$ & $8,5 \%$ & $10,9 \%$ \\
mere end 36 mdr. & $0,7 \%$ & $0,5 \%$ & $1,1 \%$ & $4,0 \%$ & $3,3 \%$ & $2,3 \%$ \\
\hline I alt & $100 \%$ & $100 \%$ & $100 \%$ & $100 \%$ & $100 \%$ & $100 \%$
\end{tabular}

Lov om samfundstjeneste trådte i kraft 1. juli 1995. Antallet af domfældte, der påbegyndte samfundstjeneste hvert år i perioden 1995-1999, er:

\begin{tabular}{lrrrrr} 
& $\mathbf{1 9 9 5}$ & $\mathbf{1 9 9 6}$ & $\mathbf{1 9 9 7}$ & $\mathbf{1 9 9 8}$ & $\mathbf{1 9 9 9}$ \\
\hline Ydet samfundstjeneste & 20 & 45 & 49 & 84 & 60 \\
Antal dage bag ydet samfundstjeneste & 905 & 1950 & 2310 & 4710 & 3645 \\
Gennemsnitslængde i dage & 45,3 & 43,3 & 47,1 & 56,1 & 60,8
\end{tabular}

Fra indgangen af 1998 var der hjemmel til at fuldbyrde op til 6 måneders fængselsdom med samfundstjeneste i stedet for tidligere 3 måneder, hvilket forklarer stigningen i samfundstjeneste mellem årene 1997 og 1998. 
Baggrunden for frihedsstraffen for de fanger, der afsonede eller blev løsladt i 1994-1999, var som følger:

\begin{tabular}{lrrrrrr} 
& $\mathbf{1 9 9 4}$ & $\mathbf{1 9 9 5}$ & $\mathbf{1 9 9 6}$ & $\mathbf{1 9 9 7}$ & $\mathbf{1 9 9 8}$ & \multicolumn{1}{c}{$\mathbf{1 9 9 9}$} \\
\hline Berigelse og dokumentfalsk & $46,7 \%$ & $42,7 \%$ & $48,0 \%$ & $43,7 \%$ & $38,1 \%$ & $39,6 \%$ \\
Brugstyveri og/eller færdselslov & $19,2 \%$ & $21,9 \%$ & $16,5 \%$ & $12,2 \%$ & $13,8 \%$ & $13,3 \%$ \\
Narkotikaforbrydelser & $10,7 \%$ & $13,8 \%$ & $13,0 \%$ & $18,3 \%$ & $20,1 \%$ & $23,8 \%$ \\
Voldsforbrydelser & $7,6 \%$ & $6,5 \%$ & $6,5 \%$ & $10,6 \%$ & $10,1 \%$ & $8,3 \%$ \\
Seksualforbrydelser & $7,0 \%$ & $7,0 \%$ & $8,2 \%$ & $8,4 \%$ & $10,4 \%$ & $8,8 \%$ \\
Manddrab eller forsøg på manddrab & $3,8 \%$ & $2,4 \%$ & $1,4 \%$ & $2,3 \%$ & $3,7 \%$ & $4,2 \%$ \\
Andet & $5,0 \%$ & $5,7 \%$ & $6,4 \%$ & $4,5 \%$ & $3,8 \%$ & $2,1 \%$ \\
\hline I alt & $100 \%$ & $100 \%$ & $100 \%$ & $100 \%$ & $100 \%$ & $100 \%$
\end{tabular}

Antallet af dem, som afsoner frihedsstraf for berigelses- og færdselslovovertrædelser falder procentvis i perioden, medens antallet af dem, der afsoner frihedsstraf for narkotikaforbrydelser, procentvis er steget betydeligt.

Antallet af fanger, der udstår frihedsstraf, er faldet betydeligt i de seneste år. De var 209 i 1994, 274 i 1995, 317 i 1996, 223 i 1997, 174 i 1998 og 157 i 1999. Arsagen til dette er bl.a. benyttelse af samfundstjeneste.

Af 157 fanger, der afsluttede afsoningen i 1999, var det den første strafafsoning for $48,4 \%$, medens $51,6 \%$ tidligere havde afsonet straf. $81,5 \%$ af fangerne tilbragte ét år eller mindre med afsoningen, og 18,5\% længere end ét år. Kvinder udgjorde 4,5\% af fangerne og mænd 95,5\%.

\section{Forskellige lovændringer}

\section{Lov om statskassens betaling af erstatninger til ofre for forbrydelser $69 / 1995$}

Lov nr. 69/1995 foreskriver, at statskassen betaler erstatning til ofre for forbrydelser. Formålet med loven er at styrke ofrenes retsstilling på den måde, at statskassen betaler erstatning for person- og immateriel skade, der er opstået som følge af overtrædelse af straffeloven, samt for skade på ting, der er følge af en sådan overtrædelse, hvis vedkommende begår forbrydelsen under tvangsanbringelse (strafafsoning, varetægtsfængsling eller tvangsmæssigt ophold på institution). Der gælder den almindelige betingelse, at overtrædelsen skal være sket på islandsk territorium, at skaden er blevet anmeldt til politiet, og at den skadelidte har gjort erstatningskrav gældende over for skadevolder. Lovens bestemmelser gælder endvidere, selv om skadevolders identitet ikke kendes, vedkommende er utilregnelig eller ikke kan findes. Afgørelse om udbetaling af erstatning tages af et særligt forvaltningsudvalg, erstatningsudvalget. Udvalget afgør, om betingelserne for betaling af erstatning er til stede, og fastsætter erstatningsbeløbet. Når der er afsagt dom vedrørende erstatningskravet, gås der i almindelighed ud fra, at erstatningen bliver udbetalt $\mathrm{i}$ overensstemmelse med dommen.

\section{Den internationale kriminaldomstol $i$ Haag}

Den 25. maj 1993 vedtog De forenede nationers sikkerhedsråd resolution nr. 827 (1993) om at oprette en international domstol med henblik på at føre straffesager mod personer, der anses for at være ansvarlige for alvorlige overtrædelser af internationale humanitære regler, begået i det tidligere Jugoslavien fra og med 1. januar 1991. Sikkerhedsrådets resolution byggede på bestemmelserne i afsnit VII i De forenede nationers konvention. For at islandske myndigheder om nødvendigt kan opfylde sine pligter over for kriminaldomstolen, vedtoges lov nr. 49/1994 om retshjælp til den internationale domstol, der behandler krigsforbrydelser i den tidligere Jugoslavien. Der findes bestemmelser om de punkter, der kræver intern lovgivning, herunder udlevering og anden retshjælp, overførelse af frihedsberøvet person til afhøring og fuldbyrdelse af kriminaldomstolens domme. 


\section{Den europaiske menneskerettighedskonvention}

Med lov nr. 62/1994 blev Den europæiske Menneskerettighedskonvention (Konvention af 4. november 1950 om beskyttelse af menneskerettigheder og de grundlæggende frihedsrettigheder med ændringer) lovfæstet i Island. Det blev endvidere vedtaget i loven, at beslutninger truffet af Den europæiske Menneskerettighedskommission, Den europæiske Menneskerettighedsdomstol og Europarådets ministerråd ikke er bindende for islandsk ret.

\section{Spirituskørsel}

Med lov nr. 48/1997 blev § 45 i færdselsloven 50/1987 ændret med henblik på ibrugtagning af nye metoder til måling af spirituspromillen i blod. De nye metoder indebærer, at spirituspromillen måles i førerens udåndingsluft. Færdselslovændringen består i, at resultatet af målingen af spirituspromillen i førerens udåndingsluft efter loven er fyldestgørende bevis for beruselse på samme måde, som når spirituspromillen måles i blodet. Med lov nr. 23/1998 blev der foretaget to ændringer af bestemmelser i færdselsloven i kølvandet af indførelsen af denne hjemmel. På den ene side blev færdselslovens $\S 47$, stk. 4 , ændret, så at den tiltalte i forbindelse med tagning og undersøgelse af udåndingsprøven skal betale $6.500 \mathrm{IKK}$, der tæller med i sagsomkostningerne. På den anden side blev færdselslovens $\S 102$ ændret, så at førerens manglende vilje til at være behjælpelig ved sagens efterforskning ved at aflevere udåndingsprøve, kan straffes med fradømmelse af kørekort i ét år.

\section{Forhøjelsen af myndighedsalderen}

Med en ny myndighedslov nr.17/1997, der trådte i kraft 1. januar 1998, blev myndighedsalderen forhøjet fra 16 til 18 år. Ifølge loven bliver er person myndig ved det fyldte 18. år, og en myndig person har evne til at forpligte sin person eller formue ved retshandler. Et af argumenterne for forhøjelsen af myndighedsalderen, var henvisningen til beskyttelse af børn. De synspunkter byggede på, at det var rigtigt at forhøje myndighedsalderen, eftersom børneværnsudvalgene ikke kunne blande sig $\mathrm{i}$ en person over 16 års anliggender uden dennes samtykke. Påbegyndt behandlingsarbejde før 16-års alderen kunne gå tabt ved myndighedsalderens indtræden ved 16 år, således at den unge ville kunne skære alle bånd over til behandlerne. Hvad angår lovovertrædelser og narkotikamisbrug blandt unge mellem 16 og 18 år blev det fremført, at forhøjelsen af myndighedsalderen gjorde det lettere at få fat $\mathrm{i}$ disse individer og gribe ind over for problemerne.

Adresse: Dadi Kristjánsson

Sysselmanden i İ́safjördur

Stjórnsýsluhúsid, Hafnarstræti 1

IS-400 Ísafjördur

dadikristjansson@isholf.is

Ragnheidur Bragadóttir

Det juridiske fakultet

Islands Universitet

IS-101 Reykjavík

rb@hi.is 